\title{
Assessment of the Necessity of Routine Lumber Puncture among Children with Fever and Convulsions
}

\author{
Nader Mutwakel Osman ${ }^{1}$ and James Peter Garkuoth Gai ${ }^{2}$ \\ ${ }^{1}$ Department of paediatric and Child Health, Fuculty of Medicine \\ ${ }^{2}$ Mohamed Al Amin Hamid Paediatric Hospital Omderuman
}

Corresponding Author: Nader Mutwakel Osman; email:

nadermosman@gmail.com

Received 21 February 2019 Accepted 12 May 2019 Published 30 September 2019

Production and Hosting by Knowledge E

(ㄷ) Nader Mutwakel Osman and James Peter Garkuoth Gai. This article is distributed under the terms of the

which

permits unrestricted use and redistribution provided that the original author and source are credited.

Editor-in-Chief:

Prof. Mohammad A. M. Ibnouf

\section{Abstract}

Background: The routine investigation of doing lumbar puncture in patient with febrile convulsion is increasing practiced in many hospital.

Objectives: The aim of this study was to assess the necessity of routine lumbar puncture (LP) to diagnose meningitis in children who present with fever and convulsions.

Methods: This is an observational, cross-sectional, hospital-based study, carried out in Mohammed AL-Amin Hamid pediatrics hospital-Omdurman Sudan, during the period from the first of January through 31 July 2018. It involved all (146) children aged 5 months to $6 y e a r s$, who presented with fever and convulsions, undergone lumbar puncture, and parents signed written informed consents. Children with known neurological diseases were excluded from this study. Data collected included, age, gender, convulsions type and duration, post-ictal state, routine vaccination status, general condition, recent antibiotics use, past history of fever and convulsions, temperature degree, signs of meningeal irritation, and conscious level. Data were analyzed by Statistical Package for Social Sciences (SPSS) version 23.

Results: The result revealed that total number of 146 children, male were $62 \%(n=91)$, female were $38 \%(n=55) .5-11$ months $35.6 \%(n=52) 1-3$ years $43.8 \%(n=64)$, and $4-6$ years $20.6 \%(n=30)$. About $80 \%$ of the patients were younger than 4 years of age. Convulsion was generalized in $97.9 \%$, lasted less than 15 minutes in 99.3\%, spontaneously aborted in $94.5 \%$, post-ictal state was brief in $88.4 \%$, first attack in $98.6 \%$, and there was no family history in $97.3 \%, p=0.000$. There was no neck stiffness and photophobia in $92.5 \%$ and $98.6 \%$ respectively, $\mathrm{p}=0.000$. Patients general condition were well in $76.7 \%$ and toxic in $23.3 \%$. Cerebrospinal fluids (CSF) color was clear in $97 \%$ and turbid in $3 \%$ of patients. CSF white cells was less than 5 in 93.8\%, and CSF sugar and protein were normal in $97.3 \%$ and $96.6 \%$ respectively, $p=0.000$. CSF culture was negative for all patients, and almost all $(97 \%, n=141)$ of the patients were diagnosed as febrile convulsions and sent home, compared to $3 \%(n=5)$ who were diagnosed clinically as meningitis.

Conclusion: This study revealed that, CSF culture was negative for all patients, and almost all were diagnosed as febrile convulsions. However, 5 patients were diagnosed clinically as meningitis. Hence, this findings, challenge the routine lumbar puncture in children who present with fever and convulsion. 


\section{Introduction}

Since the introduction of lumbar puncture (LP) in the $19^{\text {th }}$ century (1891) by . Quincke [1], it remains the most commonly used invasive diagnostic procedure. It involves insertion of a specialized needle in the lumbar spine interspaces (L3-L4 or L4-L5) in order to withdraw cerebrospinal fluids (CSF). Beside the diagnosis of meningitis and other central nervous system (CNS) infections, LP is also used to diagnose subarachnoid hemorrhage and to relief increased intracranial pressure (ICP). [1-3] it is contraindicated in critically ill patients, impaired conscious level, cardiopulmonary compromise, bleeding disorder or coagulopathy, raised intracranial pressure, and infection at the puncture site. Its Complications include introduction of traumatic (bloody) and dry tap, post-puncture headache, cerebral herniation, and hemorrhage (external and /or intracranial; epidural, subdural, and subarachnoid) [2, 3].

Seizure is a frightening event to the family, and imposes challenge to the health professionals so lumbar puncture still an important diagnostic procedure to exclude meningitis and it is curried out routinely in some settings, although the current evidence suggests selective rather than routine use. Bacterial meningitis is rare in patients with complex febrile seizures who otherwise appear well and have no other signs and symptoms on physical examination $[4,5]$.

There are two types of febrile convulsion, typical (simple) occurs in children 6 month to 5 years, generalized, lasting less than 15 minutes, does not recur within the 24 hours, and normal neurological examination, and the atypical (complex) which is localized, prolonged-lasting 15 minutes or more, recurs within the 24hours,and abnormal neurological examination [2].

According to the American Academy of Pediatrics (AAP), the febrile seizure is defined as convulsions accompanied with fever (temperature 38 degree or more) without central nervous system (CNS) infection that occurs in children 6-60 months. It is the most common convulsion occurs in $2 \%$ to $5 \%$ of all children [3]. It has been found that, sudden and prolonged rise in body temperature and upper respiratory infection predispose to febrile seizure. [6, 7] and according to the updated AAP guidelines (2011) lumbar puncture should be performed in any child who presents with fever and seizure and has history, signs and symptoms suggesting meningeal irritation or intracranial infection.But any infant aged 6 to 12months who presents with seizure and fever, a lumbar puncture is an option when the child is considered not immunized or the status of immunization is not known. Also lumbar puncture is an option in the child who presents with fever and seizure and is pretreated with antibiotics [7]. 
According to Sudanese guidelines, LP should be considered in all children aged $<$ 18 month with their first febrile convulsions, any child with suspected meningitis and any infant and child who received recent antibiotics [8].

\section{Materials and Methods}

This was a cross-sectional, observational, hospital-based study that was conducted in Mohammed AL-Amin Hamid teaching hospital (Omdurman) one of the largest pediatrics teaching hospital in Sudan, established during the period from $1^{\text {st }}$ January through $31^{\text {st }}$ July 2018. Total coverage of all children who fulfilled the inclusion criteria for all children (5 months to 6years of age) who are admitted to the emergency department with fever and convulsions and undergone lumber puncture during the study period whom parents signed written informed consents, were included in the study, with exclusion criteria of the children less than 5 months and above 6 years, and those who have known neurological disorders were excluded from the study.

Data were directly collected from the parents and patients assessment through check list questionnaire and meningitis record (a register book provided by the ministry of health in order to keep record and surveillance of the suspected cases of meningitis).

Ethical approval was obtained from Sudan medical specialization board (SMSB) ethical committee and informed consent was signed by the parent care givers.

The study variable include age, gender, convulsions type and duration, post-ictal state, routine vaccination status, patient general condition, recent antibiotics use, previous history of fever associated seizures, temperature degree, signs of meningeal irritation, and conscious level.

Data were processed by computer and analyzed using SPSS version 23.

\section{Results}

Of total 146 children, male were $62 \%(n=91)$, female were $38 \%(n=55)$-Male: female (1.6:1). $5-11$ months $35.6 \%(n=52), 1-3$ years $43.8 \%(n=64)$, and $4-6$ years $20.6 \%(n=30)$. About $80 \%$ of the patients were younger than 4 years of age. See table 1

According to history for those who received antibiotic before getting convulsion were 70 (47.9\%) and those who did not receive antibiotic were 76 (52.1\%.).

Most of the patients were vaccinated (n 114) 78\% and those not vaccinated were (n 29) $19.9 \%$ and only 3 patients their vaccination status were unknown 2.1\%. see table 2 . 
The convulsion was generalized in $97.9 \%$, lasted less than 15 minutes in $99.3 \%$, spontaneously aborted in $94.5 \%$, first attack in $98.6 \%$, and there was no family history in $97.3 \%, p=0.000$. Post-ictal state was brief in $88.4 \%$. See table 3

There was no neck stiffness or photophobia in $92.5 \%$ and $98.6 \%$ respectively. Patients general condition were well in $76.7 \%$ and toxic in $23.3 \%$ see table 4

According to investigation characteristic blood film for malaria was positive for only one patient (0.7\%) negative for 142 patients (97.2\%) and not done for 3 patients (2.1\%) see table 5. Cerebrospinal fluids (CSF) color was clear in $97 \%$ and turbid in $3 \%$ of patients, $p=0.000$. CSF white cells were less than 5 cells in $93.8 \%$, CSF sugar and protein were normal in $97.3 \%$ and $96.6 \%$ respectively, $p=0.000$. CSF culture was negative for all patients, see table 6 . And almost all $97 \%$, $(n=141)$ of them were diagnosed as febrile convulsion, and the remaining $3 \%(n=5)$ were diagnosed and treated clinically as meningitis

Interestingly, those diagnosed clinically as meningitis, were pretreated with antibiotics, not vaccinated, toxic look and have significant CSF findings (turbid color, low sugar, and high protein and white cells).

(*Statistical significance is set as $p<0.05)$.

TABLE 1: Demographic distribution of the study population $(n=146)$.

\begin{tabular}{l|c|}
$\begin{array}{l}\text { Demographical characteristics } \\
\text { Age }\end{array}$ & $\begin{array}{c}5 \text {-11 month } \\
1-3 y \text { years } \\
4-6 \text { years }\end{array}$ \\
\hline Gender & Male \\
& Female
\end{tabular}

\begin{tabular}{|c|c|}
\hline Frequency & $\%$ \\
\hline 52 & 35.6 \\
64 & 43.8 \\
30 & 20.6 \\
\hline & \\
\hline 91 & 62 \\
\hline 55 & 38 \\
\hline
\end{tabular}

TABLE 2: Distribution of the study population according to history characteristics ( $n=146)$.

\begin{tabular}{l|c|c|c|}
\hline History characteristics & & Frequency & $\%$ \\
\hline Recent antibiotics use & Yes & 70 & 47.9 \\
& No & 76 & 52.1 \\
\hline Routine vaccination status & $\begin{array}{c}\text { Vaccinated } \\
\text { Not vaccinated }\end{array}$ & 114 & 78 \\
& Status unknown & 3 & 19.9 \\
& & & 2.1 \\
\hline Patient previous history of & Yes & 2 & 1.4 \\
\hline fever and convulsion & No & 144 & 98.6 \\
\hline Family history of febrile & Yes & 4 & 2.7 \\
convulsion & No & 142 & 97.3 \\
\hline
\end{tabular}


TABLE 3: Distribution of the study population according to convulsions characteristics $(n=146)$.

\begin{tabular}{|c|c|c|c|}
\hline \multicolumn{2}{|c|}{ Convulsions characteristics } & \multirow{2}{*}{$\begin{array}{c}\text { Frequency } \\
143 \\
3\end{array}$} & \multirow{2}{*}{$\begin{array}{r}\% \\
97.9 \\
2.1\end{array}$} \\
\hline Convulsion type & $\begin{array}{l}\text { Generalized } \\
\text { Focal }\end{array}$ & & \\
\hline Convulsion duration & $\begin{array}{l}<5 \text { minutes } \\
5-15 \text { minutes } \\
>15 \text { minutes }\end{array}$ & $\begin{array}{l}120 \\
25 \\
1\end{array}$ & $\begin{array}{l}82.2 \\
17.1 \\
0.7\end{array}$ \\
\hline Post-ictal state & $\begin{array}{l}\text { Brief }(<30 \text { minutes }) \\
\text { Prolonged ( }>30 \text { minutes) }\end{array}$ & $\begin{array}{l}129 \\
17\end{array}$ & $\begin{array}{l}88.4 \\
11.6\end{array}$ \\
\hline Convulsions onset & $\begin{array}{l}<24 \text { hours after fever } \\
>24 \text { hours after fever }\end{array}$ & $\begin{array}{l}132 \\
14\end{array}$ & $\begin{array}{l}90.4 \\
9.6\end{array}$ \\
\hline Convulsion abortion & $\begin{array}{l}\text { Spontaneous } \\
\text { By diazepam } \\
\text { By phenytoin }\end{array}$ & $\begin{array}{c}138 \\
8 \\
0\end{array}$ & $\begin{array}{l}94.5 \\
5.5 \\
0\end{array}$ \\
\hline
\end{tabular}

TABLE 4: Distribution of the study population according to clinical characteristics ( $n=146)$.

\begin{tabular}{|c|c|c|c|}
\hline \multicolumn{2}{|l|}{ Clinical characteristics } & \multirow{2}{*}{$\begin{array}{l}\text { Frequency } \\
19 \\
127\end{array}$} & \multirow{2}{*}{$\begin{array}{l}\% \\
13 \\
87\end{array}$} \\
\hline Bulging anterior fontanel & $\begin{array}{l}\text { Yes } \\
\text { No }\end{array}$ & & \\
\hline $\begin{array}{l}\text { Kerning's and or } \\
\text { Brudzinski's sign }\end{array}$ & $\begin{array}{l}\text { Positive } \\
\text { Negative } \\
\text { Not done } \\
\text { Not applicable }\end{array}$ & $\begin{array}{l}2 \\
46 \\
30 \\
68\end{array}$ & $\begin{array}{l}1.4 \\
31.5 \\
20.5 \\
46.6\end{array}$ \\
\hline Neck stiffness & $\begin{array}{l}\text { Positive } \\
\text { Negative }\end{array}$ & $\begin{array}{c}11 \\
135\end{array}$ & $\begin{array}{l}7.5 \\
92.5\end{array}$ \\
\hline Photophobia & $\begin{array}{c}\text { Yes } \\
\text { No } \\
\text { Not checked }\end{array}$ & $\begin{array}{c}1 \\
144 \\
1\end{array}$ & $\begin{array}{l}0.7 \\
98.6 \\
0.7\end{array}$ \\
\hline Patient general condition & $\begin{array}{l}\text { Well } \\
\text { Toxic }\end{array}$ & $\begin{array}{l}112 \\
34\end{array}$ & $\begin{array}{l}76.7 \\
23.3\end{array}$ \\
\hline Fever & $\begin{array}{l}\text { High grade } \\
\text { Low grade }\end{array}$ & $\begin{array}{c}141 \\
5\end{array}$ & $\begin{array}{l}96.6 \\
3.4\end{array}$ \\
\hline
\end{tabular}

\section{Discussion}

This cross-sectional, observational study attempts to investigate the necessity of routine lumbar puncture in children who present with fever and convulsions, because there is no well-established data or studies in our community regarding this matter. As bacterial meningitis is a life threatening infectious disease affecting the meninges, 
TABLE 5: Distribution of the study population according to investigation characteristics ( $\mathrm{n}=146$ ).

\begin{tabular}{|c|c|c|c|}
\hline \multicolumn{2}{|l|}{ Investigations } & \multirow{2}{*}{$\begin{array}{c}\text { Frequency } \\
0 \\
146\end{array}$} & \multirow{2}{*}{$\begin{array}{c}\% \\
0.0 \\
100\end{array}$} \\
\hline Gram stain & $\begin{array}{l}\text { Positive } \\
\text { Negative }\end{array}$ & & \\
\hline Blood film for malaria & $\begin{array}{l}\text { Positive } \\
\text { Negative } \\
\text { Not done }\end{array}$ & $\begin{array}{c}1 \\
142 \\
3\end{array}$ & $\begin{array}{c}0.7 \\
97.2 \\
2.1\end{array}$ \\
\hline C-Reactive protein (CRP) & $\begin{array}{l}\text { Positive } \\
\text { Negative } \\
\text { Not done }\end{array}$ & $\begin{array}{c}1 \\
2 \\
143\end{array}$ & $\begin{array}{l}0.7 \\
1.4 \\
97.9\end{array}$ \\
\hline Blood culture & $\begin{array}{l}\text { Done } \\
\text { Not done }\end{array}$ & $\begin{array}{c}0 \\
146\end{array}$ & $\begin{array}{l}0.0 \\
100\end{array}$ \\
\hline Latex Agglutination Test & $\begin{array}{l}\text { Done } \\
\text { Not done }\end{array}$ & $\begin{array}{c}0 \\
146\end{array}$ & $\begin{array}{l}0.0 \\
100\end{array}$ \\
\hline Fundal examination before LP & $\begin{array}{l}\text { Done } \\
\text { Not done }\end{array}$ & $\begin{array}{c}0 \\
146\end{array}$ & $\begin{array}{c}0.0 \\
100\end{array}$ \\
\hline CT brain before LP & $\begin{array}{l}\text { Done } \\
\text { Not done }\end{array}$ & $\begin{array}{c}0 \\
146\end{array}$ & $\begin{array}{l}0.0 \\
100\end{array}$ \\
\hline
\end{tabular}

TABLE 6: Distribution of the study population according to CSF results ( $n=146$ ).

CSF results
CSF white cells
CSF Protein
CSF sugar
CSF culture
CSF color

$<5$
$5-100$
$100-500$
$>500$
Normal
Elevated
Markedly elevated

Normal
Low
Markedly low
Positive
Negative
Clear
Turbid
Red

\begin{tabular}{|l} 
Frequency \\
137 \\
6 \\
2 \\
1 \\
\\
141 \\
4 \\
1 \\
\\
142 \\
3 \\
1 \\
\\
0 \\
146 \\
139 \\
5 \\
2 \\
\hline
\end{tabular}

\begin{tabular}{|c|}
\hline \multicolumn{1}{c}{$\%$} \\
\hline 93.8 \\
4.1 \\
1.4 \\
0.7 \\
\hline \\
\hline 96.6 \\
2.7 \\
0.7 \\
\hline 97.3 \\
2 \\
0.7 \\
\\
\hline 0 \\
100 \\
\\
\hline 95.2 \\
3.4 \\
1.4
\end{tabular}

and the commonest organism are Haemophilus influenza type b (Hib), Streptococcal Pneumonae, Neissaria meningitides, and group B streptococci (GBS) [9]. 
In Africa, bacterial meningitis occurs mainly within the meningitis belt, and Sudanwhich falls within this belt, accounts for about 2 in every 100 cases of meningitis. But, the prevalence and incidence of meningitis in Sudan significantly reduced since the introduction of Hib, Pneumococcal, and meningococcal type A vaccines into Sudan immunization schedule in 2008, 2013, and 2016 respectively [10, 11]. Generally, with the increasing coverage of vaccination, the morbidity and mortality from the commonest causes of bacterial meningitis is dramatically reduced $[12,13]$.

Antibiotic pretreatment (recent antibiotics use) is said to affect the clinical features of meningitis, that is why it is stated that LP should be carried out in children with fever and seizures who received antibiotic [8-15]. As it has been found in a recent study that, CSF will become sterile for meningococcal and pneumococcal bacteria in 2 and 4 hours of third generation cephalosporin antibiotics respectively [16].

Several studies had been done in the world for the need to do lumbar puncture for patients with febrile convulsion or not.As for the retrospective cohort review for children aged 6 to 18 months by Kimia in 2009 found the risk of bacterial meningitis presenting as first simple febrile seizure is very low. And they recommend that, the current AAP guidelines should be reconsidered [17]

Also a retrospective cross sectional observational study done by Auvin in 2017 and Oluwabusi. Curr Opin investigating infants aged 6-11 months with conclusion that, the risk of bacterial meningitis is extremely low in children with simple febrile convulsions [18].

A systemic review and meta-Analysis done by Najaf-Zadeh revealed that, the utility of routine lumbar puncture for the diagnosis of central nervous system (CNS) infection, is very low. Similar results were obtained by Hom J. In a systemic review which concluded that, the risk of bacterial meningitis in children presenting with simple febrile convulsions is very low $[19,20]$.

Majority of our study population in this study, have features suggestive of first simple febrile convulsions (generalized, brief, spontaneously aborted, normal neurological and CSF examination), and about $80 \%$ of them received routine vaccination according to the national immunization schedule, And almost all (97\%) were sent home with the final diagnosis of febrile convulsions, once the CSF biochemistry was normal and CSF culture showed negative results on the third day of sample collection, compared to $3 \%$ whom were diagnosed clinically as meningitis, figure [7].

Interestingly, those diagnosed clinically as meningitis, were pretreated with antibiotics, not vaccinated, toxic at presentation, and have significant CSF findings (turbid color, low sugar, and high protein and white cells). 
The findings of our study are supported by the updated American academy of paediatric (AAP) guideline [7], and prospective studies by Ghotbi et al. [14], and Laman et al. [21], another similar results were obtained from retrospective studies by Kimia AA et al. [7], Casasoprana A et al. [22] and Azita T et al. [23].

Many studies attempt to identify the risks and predictors of meningitis in children who present with fever and convulsions. Prolonged seizures (lasting more than $\mathbf{3 0}$ minutes), first attack, post-ictal drowsiness, fever and complex convulsions, impaired conscious level, body temperature 38 or more, age younger than 18 months, and neurological deficits were found to be predictive of meningitis in children presented with fever and convulsions $[24,25,26]$.

In contrast to these findings, few studies as for Joshi Batajoo et al. [27] have done a prospective study which stated that, LP is necessary to rule out meningitis in infants 6-12 months who present with fever and convulsions even in the absence of meningeal signs. Another retrospective study which investigated children younger than 12 month, concluded that, LP should be considered in all infants with simple febrile seizure even if fully vaccinated [28].

Supported by the above mentioned studies, our study provides another evidence that, routine lumbar puncture in children who present with fever and simple generalized convulsion, clinical assessment supports the diagnosis of simple febrile convulsions, fully vaccinated and not received antibiotic is not necessary.

Our study sustained some limitations, being a single center study and a rather small sample size, renders the results not generalizable. A wider multi-center research is needed.

\section{Conclusion}

Investigating the need for routine lumbar puncture in children who present with fever and convulsions was the aim of this study. This research revealed that, CSF culture was negative for all patients, and almost all were diagnosed as febrile convulsions. However, 5 patients were diagnosed clinically as meningitis and treated accordingly. Our study revealed that, the utility of routine lumbar puncture for the diagnosis of central nervous system (CNS) infection, is very low Hence, these findings challenge the necessity of routine LP to diagnose meningitis in the absence of positive physical signs and symptoms suggestive of central nervous system infection. 


\section{Acknowledgement}

The authors express their sincere appreciation to the administration of Mohammed AL-Amin Hamid pediatrics hospital-Omdurman Sudan for giving the approval and assistance in conducting the research and we are grateful to parent and doctor who participate in the study

\section{References}

[1] Pearce JM. Walter Essex Wynter, Quincke, and lumbar puncture. J Neurol Neurosurgery Psychiatry. 1994; 57(2):179.

[2] Medscape/meningitis

[3] Nelson's textbook of pediatric 19th edition. 2090/2610

[4] Kimia AA, et al. Yield of lumbar puncture among children who present with their first complex febrile. Pediatrics.2010;126(1): 62-69

[5] Erin M. Fletcher and GhazalaSharieff. West J Emerg Med. May 2013; 14(3): 206-211.

[6] Gontko-Romanowska $\mathrm{K}$ et al.: The assessment of risk factors for febrile seizures in children. NeurolNeurochir Pol. 2017 Nov - Dec; 51(6):454-458. doi: 10.1016/j.pjnns.2017.07.011. Epub 2017 Jul 31

[7] Subcommittee on, American A. Neurodiagnostic evaluation of the child with a simple febrile seizure.Pediatrics.2011; 127 (2): 389-384.

[8] Sudanese management protocol for pediatric emergencies, 3rd edition, 2015.28 $/ 176$

[9] Mohammad M Attarpour et al. Iran J Microbiol. 2014 Aug; 6(4): 211-218.

[10] IPUMS-DHS (Demographic and health surveys

[11] WHO-Sudan first to introduce life-saving meningococcal type a vaccine into routine immunization.

[12] Wahl B, et al. Lancet Global Health.2018)

[13] Guidelines for the management of suspected and confirmed bacterial meningitis in Canadian children. Updated Dec. 2018

[14] Ghotbi F, et al. An assessment of the necessity of lumbar puncture in children with seizure and fever J Pak Med Assoc. 2009

[15] Reet S, et al. Pediatrics in Review. August 2013, vol.34/Issue 8.

[16] Reet S, et al. Pediatrics in Review. August 2013, vol.34/Issue 8. 
[17] Kimia AA, et al. Utility of lumbar puncture for first simple febrile seizure among children 6 to 18 month of age. Pediatrics.2009

[18] Guedj R, et al. Acad Emerg Med. 2015

[19] Hom J, et at. Acad Emerg Med. 2011

[20] Najaf-Zadeh et al. Risk of bacterial meningitis in young children with a first seizure in the context of fever: A systemic review and meta-Analysis

[21] Laman M, et al. Cli Infect Dis. 2010

[22] Casasoprana A, et al. Value of lumbar puncture after a first febrile seizure in children aged less than 18months. Arch pediatr 2013 involving 157 children

[23] Azita TAVASOLI et al. Frequency of meningitis in children presenting with febrile seizures. Iran J child neurol. 2014 Autumn;8(4): 51-56

[24] WHO recommendations 2015. 